\section{The effect of bud density on the composition of colour in red wines}

\author{
Barócsi Z., Balogh I., Kállay M. and Lukácsy G. \\ Szent István University, Department of Viticulture and Enology, \\ Budapest, Villányi u. 35-43, H-1118
}

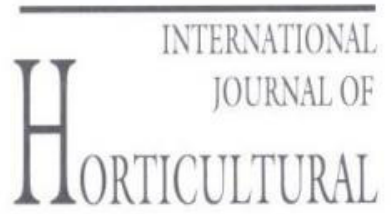
SCIENCE

AGROINFORM

Publishing House, Hungary

Key words: red wine, colour substances, fruit load

Summary: Authors investigated the effect of fruit load on the composition of colour substances and of reservatrol in red wines of some grape varieties grown in Hungary. The content of both, anthocyanin compounds and reservatrol showed practically the same responses to fruit load and the same profile in all the varieties studied. Determination of these compounds solely is not sufficient to identify the respective grape variety.

\section{Introduction}

The quality of the grapes is influenced mainly by the effect of the variety, the growing site and the vintage. Among those factors the vintage can not be controlled, virtually, whereas the site and the choice of variety are subject to economical considerations, so we are constrained to compromises. The quality depends considerably on the yield per area. On the one hand, yield is genetically limited; on the other hand it is modified by the structure of plantation, i.e. the rootstock, the training system and the spacing of rows and plants. The most important factor of building up quality is yield, which in turn is modified also by fitotechnical means.

Investigation was the objective of several attempts of researchers aiming to find out the causal relations between yield and quality especially of the colour composition in the wine produced (Guidoni \& Schubert, 2000; De La Hera Orts et al., 2000). Albeit the compounds originating from grape go through different physico-chemical and biochemical changes, significant difference could be noticed between components of wines in plantations, which had different yields.

The yield is regulated efficiently by cultivation technology, first of all by pruning. So the number of buds, which are permitted to grow shoots on the stocks, limits fruit load. Practically, the grape quality of every variety decreases with the increasing fruit load beyond a certain level. Declining quality is expressed in a lower brix grade, increasing acid content, moreover, in unfavourably changes of acid compounds. Similarly, quality decreases also to a certain degree if pruning was too heavy. That means low bud densities may break down the productive balance. The fruit load becomes unusually low, leaf area per unit of yield increases causing self-shading especially in those varieties which are known to grow thick foliage. Generally, red grapes react more sensitively than white grape varieties, as in the former we have to expect changes in polyphenolic compounds, especially in the quantity of colour substances.

In the present publication results of four years in a longterm experiment are reported. The effect of fruit load has been checked in three different red grape varieties. The bulk of data available prove unambiguously that yield and wine quality depend on the level fruit load. Among components of quality the composition of polyphenols has been stressed in wine samples of the year 1999. The different anthocyanines, as well as the ratio of acylised and not acylised derivatives are important from the point of view of colour stability. It is a known fact that the anthocyanin composition of different varieties is typical causing the characteristic colour of the respective variety. We would like to demonstrate by the proofs presented how much pruning as a viticultural technique may change the composition of colour in red wines. We also examined the formation of resveratrol, a phytoalexin, which was found also in other plant families (e.g. stilbenes) having beneficial physiological effect on heart and circulatory diseases. The occurrence of that compound among others has been related to the level of fruit load.

\section{Material and method}

The information gathered on the experimental plantations is reported in Table 1.

There are four levels of fruit load examined in the experiment:

load 0: 2 buds $/ \mathrm{m}^{2}$ (one half long shoot $/$ stock)

load 1: 3.8 buds $/ \mathrm{m}^{2}$ (one whole long shoot $/$ stock)

load 2: 7.6 buds $/ \mathrm{m}^{2}$ (two whole long shoots/stock)

load 3: 11.4 buds $/ \mathrm{m}^{2}$ (three whole long shoots/stock) 
Table I - Characterisation of the plantations

\begin{tabular}{|c|c|c|c|c|c|}
\hline Variety \& clone & Growing site & Category of quality of the site & Year of planting & Area per vinestock $\left(\mathrm{m}^{2}\right)$ & Type of training \\
\hline \multicolumn{6}{|l|}{ Kékfrankos } \\
\hline $\mathrm{M} 6 / 44$ & Eger & & & & \\
\hline Kôlyuktetô & First class & 1989 & 3.15 & umbrella & \\
\hline \multicolumn{6}{|l|}{ Kékoporto } \\
\hline $\mathrm{K}+1$ & Eger & & & & \\
\hline Dobrányi dülô & First class & 1988 & 2.97 & umbrella & \\
\hline Pinot noir & Kerecsend & & & & \\
\hline Öreg-hegy & First class & 1982 & 3.15 & umbrella & \\
\hline Loads: see the text & & & & & \\
\hline
\end{tabular}

Each level of load was represented in three replications with 10-15 stocks per plot randomly distributed in the plantation. The viticultural data were processed according to the three replications, the vinicultural data according to the levels of fruit load. The assessment of vine-stocks and indices of fertility supplemented the phytotechnical data. During the growing season the photosynthetic activity and indices of leaf area were determined. Yield and mean mass of bunches were registered as well as density and acidity of must obtained at the moment of vintage.

\section{Preparation of the wine samples}

In the vintage of $1999,20 \mathrm{~kg}$ clean fruit samples were weighed of each of the blue grape varieties: Kékfrankos, Kékoporto and Pinot noir. The squashed berries were fermented on husk after having been inoculated with selected yeast. The mash was pressed on about the $12^{\text {th }}$ day and $100 \mathrm{mg} / \mathrm{l} \mathrm{SO}_{2}$ was added to the juice. At cellar temperature $\left(12-14^{\circ} \mathrm{C}\right)$ the samples were drawn off after 8-10 days and stored in glass balloons filled up completely.

\section{Determination of the colour substances}

The components of anthocyanines were identified by HPLC techniques according to a modified method of Waterhous et al. (1994). Its advantage is that no preparation of the samples is needed.

The device: HP 1050 HPLC

Detector: UV (diode series)

Column: $\quad$ ODS Hypersil C-18 $(100 \mathrm{~mm})$

$\lambda \quad 520 \mathrm{~nm}$

T: $\quad 25^{\circ} \mathrm{C}$

flow: $\quad 0.5 \mathrm{ml} / \mathrm{min}$

Separation: by gradient elution

\section{Eluents:}

Solution A: $\quad \mathrm{NH}_{4} \mathrm{H}_{2} \mathrm{PO}_{4} 50 \mathrm{mMol}, \quad \mathrm{pH}=2.6$

Solution B: Solution A 20\% acetonitril $80 \%$

Solution C: $\quad \mathrm{H}_{3} \mathrm{PO}_{4} 0.2 \mathrm{Mol}$ adjusted to $\mathrm{pH}=1.5$ by $\mathrm{NH}_{4} \mathrm{OH}$
Program of gradients expressed in minutes

\begin{tabular}{|c|c|c|}
\hline Solution A & Solution B \% & Solution C \% \\
\hline 0 & 8 & 92 \\
\hline 20 & 20 & 80 \\
\hline 25 & 30 & 70 \\
\hline 30 & 40 & 60 \\
\hline $\begin{array}{l}35 \\
-2\end{array}$ & 80 & 20 \\
\hline$(100 \%$ Solution A) 40 & 0 & 0 \\
\hline
\end{tabular}

To the identification of the components the standards of FLUKA \& ROTH Ltd were used comparing the maxima of their absorption $\left(\mathrm{A}_{\max }\right)$ as displayed in Table 2.

Table 2 - Absorption maxima of the anthocyanin components

\begin{tabular}{|l|c|}
\hline \multicolumn{1}{|c|}{ Compound } & Amax (nm) \\
\hline delphidinin-3-monoglycoside & 520 \\
cyanidin-3-monoglycoside & 520 \\
petunidin-3-monoglycoside & 520 \\
peonidin-3-monoglycoside & $512-514$ \\
malvidin-3-monoglycoside & 522 \\
cyanidin-3-glycoside-acetate & $514-516$ \\
petunidin-3-glycoside-acetate & 528 \\
peonidin-3-glycoside-acetate & 516 \\
malvidin-3-glycoside-acetate & 528 \\
peonidin-3-glycoside-(p-cumarate) & 522 \\
malvidin-3-glycoside-(p-cumarate) & 534 \\
Waterhaus et al. (1994) & \\
\hline
\end{tabular}

\section{Determination of the isomeres of Reservatrol}

Reservatrol isomeres, the physiologically active substances, are determined by the procedure of Kállay-Török (1997) by injection HPLC method. The decisive characters from the point of view of vinification are the tint of colour, colour intensity, the conent of total polyphenols, catechin, anthocyanin, leuco-anthocyanin, which are treated by usual spectro-photometry, whereas content of alcohol and extracts by picnometer.

\section{Results and conslusions}

Most interest of the many data available are assigned to the composition of colour, which are presented as wine characteristics of the respective grape varieties (Tables 3, 4,5). 
Table 3 - Yield and parameters of wine quality of the variety Kékfrankos (vintage 1999)

\begin{tabular}{|c|c|c|c|c|c|c|c|}
\hline $\begin{array}{l}\text { Bud load } \\
\text { (buds } / \mathrm{m}^{2} \text { ) }\end{array}$ & Must density (Mmo) & Yield (t/ha) & Colour intensity & Colour tint & Total of polyphenol (mg/l) & Catechin (mg/l) & $\begin{array}{c}\text { Leuco } \\
\text { anthocyanin } \\
(\mathrm{mg} / \mathrm{l})\end{array}$ \\
\hline 2.0 & 19.6 & 0.57 & 1.90 & 0.94 & 901 & 289 & 763 \\
\hline 3.8 & 19.4 & 0.58 & 2.14 & 0.91 & 1003 & 318 & 714 \\
\hline 7.6 & 18.4 & 1.38 & 2.63 & 0.82 & 866 & 238 & 667 \\
\hline 11.4 & 18.7 & 1.30 & 3.05 & 0.62 & 944 & 274 & 709 \\
\hline
\end{tabular}

Table 4-Yield and parameters of wine quality of the variety Kékoporto (vintage 1999)

\begin{tabular}{|c|c|c|c|c|c|c|c|}
\hline $\begin{array}{l}\text { Bud load } \\
\text { (buds } / \mathrm{m}^{2} \text { ) }\end{array}$ & Must density (Mmo) & Yield (t/ha) & Colour intensity & Colour tint & Total of polyphenol $(\mathrm{mg} / \mathrm{l})$ & Catechin $(\mathrm{mg} / \mathrm{l})$ & $\begin{array}{c}\text { Leuco } \\
\text { anthocyanin } \\
(\mathrm{mg} / \mathrm{l})\end{array}$ \\
\hline 2.0 & 19.8 & 0.26 & 3.09 & 0.93 & 1298 & 589 & 541 \\
\hline 3.8 & 20.8 & 0.97 & 3.65 & 0.97 & 1319 & 748 & 792 \\
\hline 7.6 & 20.2 & 1.23 & 3.62 & 0.93 & 1291 & 642 & 852 \\
\hline 11.4 & 21.0 & 1.38 & 2.98 & 0.94 & 1115 & 477 & 465 \\
\hline
\end{tabular}

Table 5 - Yield and parameters of wine quality of the variety Pinot noir (vintage 1999)

\begin{tabular}{|c|c|c|c|c|c|c|}
\hline $\begin{array}{c}\text { Bud load } \\
\left.\text { (buds } / \mathrm{m}^{2}\right)\end{array}$ & Must density (Mmo) & Yield (t/ha) & Colour intensity & Colour tint & $\begin{array}{c}\text { Leuco } \\
\text { Total of polyphenol (mg/l) }\end{array}$ & $\begin{array}{c}\text { Catechin (mg/l) } \\
\text { anthocyanin } \\
(\mathrm{mg} / 1)\end{array}$ \\
\hline 3.8 & 19.1 & 0.98 & 1.22 & 0.88 & 758 \\
7.6 & 19.6 & 1.47 & 1.28 & 0.80 & 811 \\
11.4 & 20.0 & 1.71 & 1.08 & 0.91 & 332 \\
\hline
\end{tabular}

Results are published in Table 6, 7 and 8/a, and more easily to be visualised in Figures $I$ to 7 .

Table 6 - Effect of bud load on the composition of colour substances (Kékfrankos)

\begin{tabular}{|c|c|c|c|c|}
\hline Compound $(\mathrm{mg} / \mathrm{l})$ in $\mathrm{MD}$ & load 0 & load 1 & load 2 & load 3 \\
\hline delphidinin-3-monoglycoside & 1.85 & 2.23 & 0.00 & 1.68 \\
\hline cyanidin-3-monoglycoside & 0.00 & 0.00 & 0.00 & 0.00 \\
\hline petunidin-3-monoglycoside & 5.46 & 5.09 & 3.00 & 6.53 \\
\hline peonidin-3-monoglycoside & 7.33 & 9.28 & 1.35 & 2.75 \\
\hline malvidin-3-monoglycoside & 136.23 & 127.96 & 83.42 & 130.57 \\
\hline cyanidin-3-glycoside-acetate & 0.00 & 0.00 & 0.00 & 0.00 \\
\hline petunidin-3-glycoside-acetate & 0.00 & 0.99 & 1.66 & 1.83 \\
\hline peonidin-3-glycoside-acetate & 0.00 & 0.00 & 1.03 & 0.43 \\
\hline malvidin-3-glycoside-acetate & 4.75 & 0.00 & 3.11 & 6.91 \\
\hline peonidin-3-glycoside-(p-cumarate) & 0.00 & 0.00 & 0.00 & 0.00 \\
\hline malvidin-3-glycoside-(p-cumarate) & 2.52 & 3.04 & 4.13 & 4.72 \\
\hline
\end{tabular}

MD: malvidin-3,5-diglycoside

Table 6/a-Effect of bud load on resveratrol and on some colour compounds (Kékfrankos, 1999)

\begin{tabular}{|c|c|c|c|c|c|}
\hline & $\begin{array}{c}\text { Total anthocyanins } \\
\mathrm{mg} / \mathrm{l}\end{array}$ & $\stackrel{\Sigma \text { of }}{\text { acylated compounds \% }}$ & $\mathrm{V}_{\mathrm{Ac} / \mathrm{Cu}}$ & Cis-resveratrol mg/l & Trans-resveratrol mg/l \\
\hline load 0 & 158.14 & 4.50 & 1.88 & 3.45 & 1.85 \\
\hline load 1 & 148.59 & 2.70 & 0.33 & 2.44 & 1.86 \\
\hline load 2 & 97.70 & 10.16 & 1.40 & 2.50 & 1.74 \\
\hline load 3 & 155.42 & 8.94 & 1.94 & 2.31 & 1.60 \\
\hline
\end{tabular}

$\Sigma$ acylated compounds \% means the ratio of acylated compounds related to the concentration of all anthocyanins

$\mathrm{V}_{\mathrm{Ac} / \mathrm{Cu}}$ means the ratio of anthocyanin.glycoside-acetates and cumarates 
Table 7 - Effect of bud load on the composition of colour substances (Kékoporto)

\begin{tabular}{|c|c|c|c|}
\hline compound $(\mathrm{mg} / \mathrm{l})$ in MD & load 0 & load 2 & load 3 \\
\hline delphidinin-3-monoglycoside & 8.20 & 3.13 & 3.71 \\
\hline cyanidin-3-monoglycoside & 0.00 & 0.00 & 0.00 \\
\hline petunidin-3-monoglycoside & 16.06 & 7.32 & 10.90 \\
\hline peonidin-3-monoglycoside & 7.28 & 3.62 & 3.87 \\
\hline malvidin-3-monoglycoside & 143.93 & 111.94 & 111.16 \\
\hline cyanidin-3-glycoside-acetate & 0.22 & 0.00 & 0.00 \\
\hline petunidin-3-glycoside-acetate & 6.21 & 1.67 & 1.62 \\
\hline peonidin-3-glycoside-acetate & 2.04 & 0.00 & 0.00 \\
\hline malvidin-3-glycoside-acetate & 18.11 & 13.67 & 13.61 \\
\hline peonidin-3-glycoside-(p-cumarate) & 0.00 & 0.00 & 0.00 \\
\hline malvidin-3-glycoside-(p-cumarate) & 4.98 & 7.48 & 6.22 \\
\hline
\end{tabular}

MD: malvidin-3,5-diglycoside

Table 7/a-Effect of bud load on resveratrol and on some colour compounds (Kékoporto. 1999)

\begin{tabular}{|l|c|c|c|c|}
\hline & $\begin{array}{c}\text { Total anthocyanins } \\
\mathrm{mg} / \mathrm{l}\end{array}$ & $\begin{array}{c}\Sigma \text { of } \\
\text { acylated compounds } \%\end{array}$ & $\mathrm{~V}_{\text {Ac/Cu }}$ & Cis-resveratrol mg/l \\
\hline load 0 & 207.03 & 15.27 & 5.34 & 1.81 \\
load 2 & 148.83 & 15.33 & 2.05 & 1.89 \\
load 3 & 151.09 & 14.20 & 2.45 & 1.26 \\
\hline
\end{tabular}

$\Sigma$ acylated compounds \% means the ratio of acylated compounds related to the concentration of all anthocyanins

$\mathrm{V}_{\mathrm{Ac} / \mathrm{Cu}}$ means the ratio of anthocyanin.glycoside-acetates and cumarates

Table 8

\begin{tabular}{|l|c|c|}
\hline \multicolumn{1}{|c|}{ Compound (mg/l) in MD } & load 0 & load 2 \\
\hline delphidinin-3-monoglycoside & 0.00 & 0.00 \\
cyanidin-3-monoglycoside & 0.00 & 0.00 \\
petunidin-3-monoglycoside & 0.00 & 0.00 \\
peonidin-3-monoglycoside & 0.00 & 0.97 \\
malvidin-3-monoglycoside & 56.37 & 34.48 \\
cyanidin-3-glycoside-acetate & 0.00 & 0.00 \\
petunidin-3-glycoside-acetate & 0.00 & 0.00 \\
peonidin-3-glycoside-acetate & 0.00 & 0.00 \\
malvidin-3-glycoside-acetate & 0.00 & 0.00 \\
peonidin-3-glycoside-(p-cumarate) & 0.00 & 0.00 \\
malvidin-3-glycoside-(p-cumarate) & 1.64 & 0.00 \\
\hline
\end{tabular}

MD: malvidin-3,5-diglycoside

Table $8 / a$

\begin{tabular}{|c|c|c|c|c|c|}
\hline & $\begin{array}{c}\text { Total anthocyanins } \\
\mathrm{mg} / \mathrm{l}\end{array}$ & $\frac{\Sigma \text { of }}{\text { acylated compounds } \%}$ & $\mathrm{~V}_{\mathrm{Ac} / \mathrm{Cu}}$ & Cis-resveratrol $\mathrm{mg} / \mathrm{l}$ & Trans-resveratrol mg/l \\
\hline load 0 & 58.01 & 2.83 & 0.00 & 3.28 & 1.07 \\
\hline load 2 & 35.63 & 0.52 & 0.00 & 2.72 & 1.27 \\
\hline load 3 & 61.54 & 1.20 & 0.00 & 3.29 & 1.05 \\
\hline
\end{tabular}

$\Sigma$ acylated compounds \% means the ratio of acylated compounds related to the concentration of all anthocyanins

$\mathrm{V}_{\mathrm{Ac} / \mathrm{Cu}}$ means the ratio of anthocyanin.glycoside-acetates and cumarates 


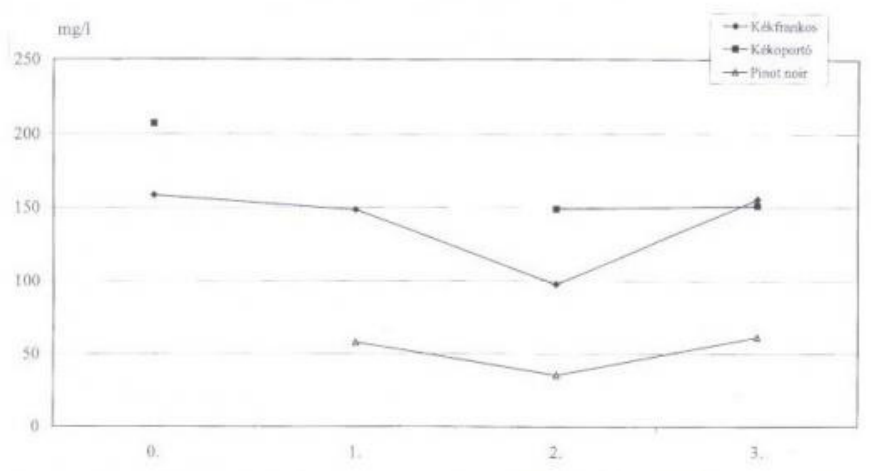

Figure 1 - Changes in the concentration of total anthocyanins as an function of bud load

$\mathrm{X}=$ bud load $(0,1,2,3) \quad \mathrm{Y}=\mathrm{mg} / \mathrm{l}$

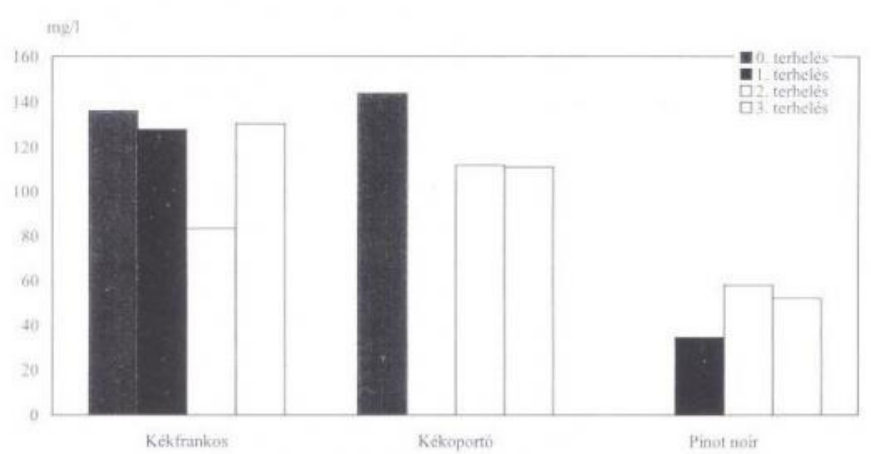

Figure 2 - Changes in the concentration of malvidin-3-monoglycoside as an function of bud load
0 , terhelés $=$ load 0
1. terhelés $=$ load 1
stb.

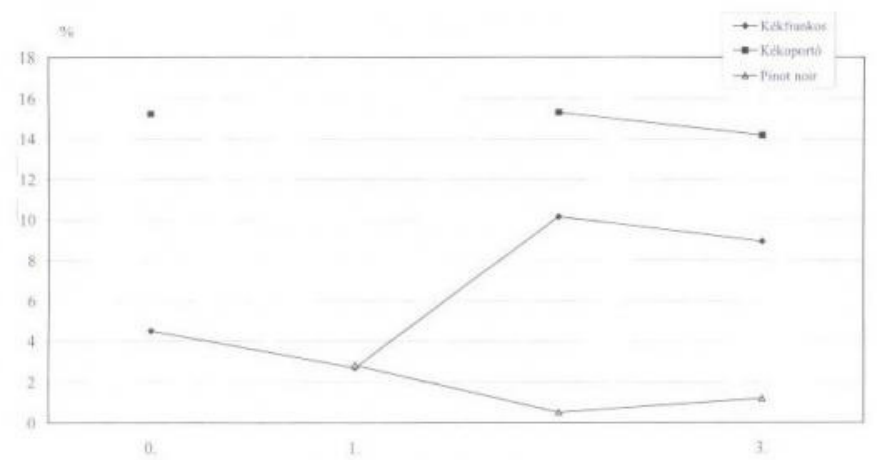

Figure 3 - The ratio (\%) of acylated compounds as a function of bud load $\mathrm{X}=$ bud load $(0,1,2,3) \quad \mathrm{Y}=\mathrm{mg} / \mathrm{l}$

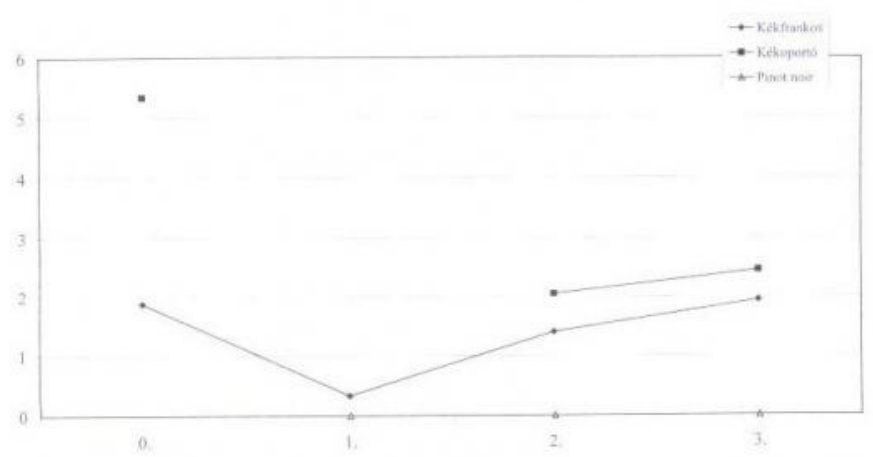

Figure 4 - Changes in the ratio of glycoside-acetates and glycosidecumarates as a function of bud load

$\mathrm{X}=$ bud load $(0,1,2,3) \quad \mathrm{Y}=\mathrm{mg} / \mathrm{l}$

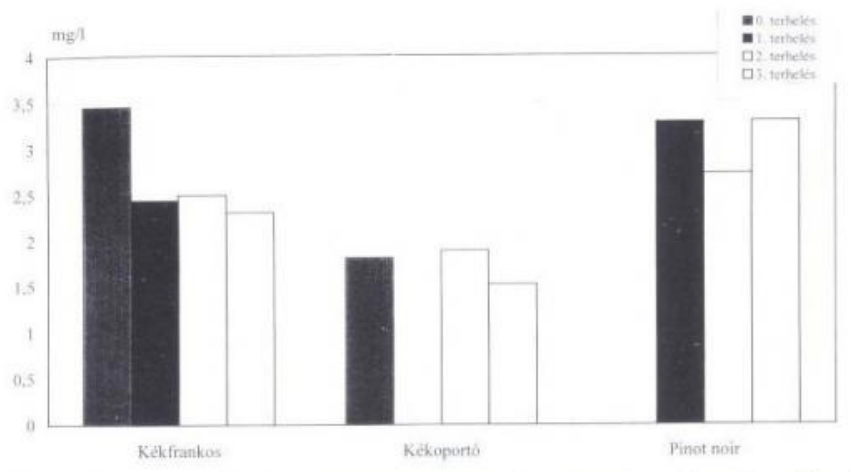

Figure 5 - Changes in the concentration of cis-reversol as a function of bud load

0. terhelés $=$ load $0 \quad$ 1. terhelés $=$ load 1

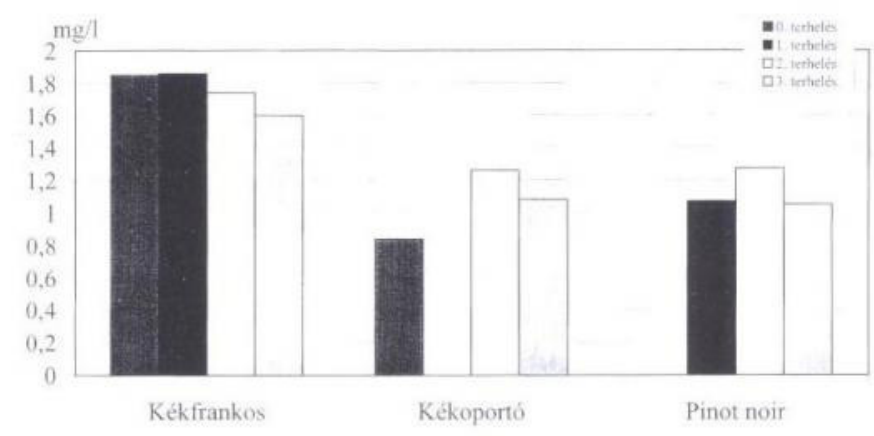

Figure 6 - Changes in the concentration of trans-reversol as a function of bud load

0. terhelés $=$ load $0 \quad$ 1. terhelés $=$ load 1

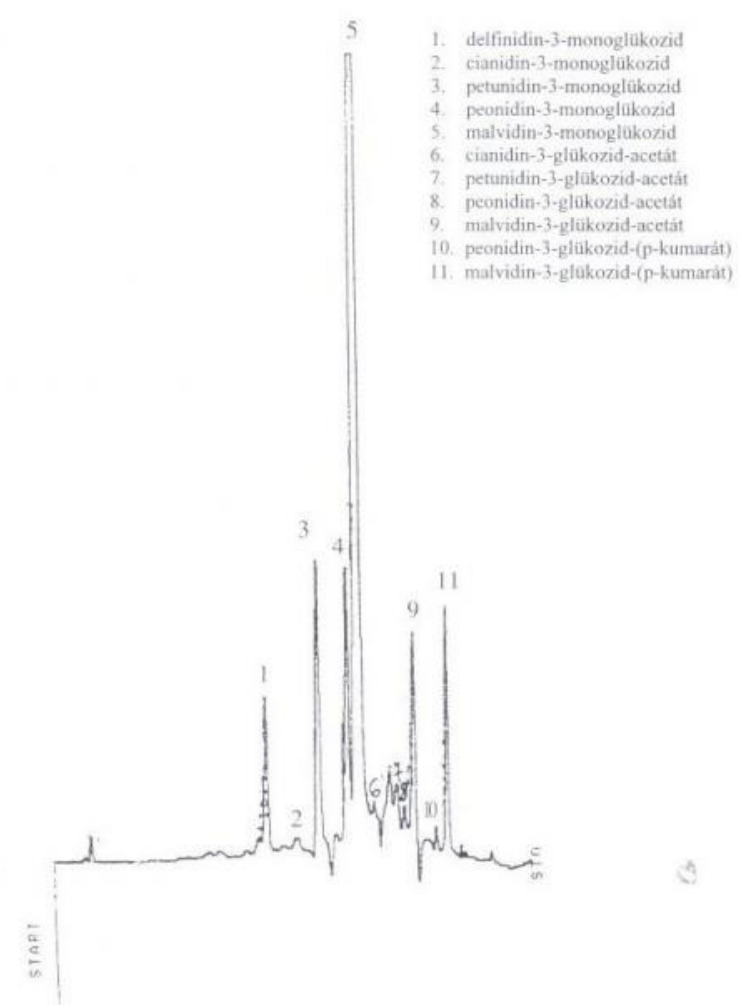

Figure 7-Composition of colour substances in the wine of Kékfrankos (at bud load 0 ) 
All of the three varieties observed prove the effect of the load of buds on the composition of colour substances, included also the formation of acylated compounds, which may turn out to be specific on the variety.

Some parameters, which are considered as characteristic of the variety $(\Sigma \mathrm{ac} \%, \mathrm{Vac} / \mathrm{Cu})$ are equally functions of the fruit load.

Among the varieties the wine of Pinot noir contains only a minimum of acylated derivatives.

The concentration of both the trans- as well as the cisreservatrol depends on fruit load. By purposeful viticultural technologies the yield of reservatrol concentration is susceptible to be increased.

Generally, it should be stated that the colour composition of a red wine is not sufficient to infer immediately to the identity of the respective variety.

\section{References}

Csepregi P. (1982): A szổổ metszése, fitotechnikai mûveletei. Mezốgazdasági Kiadó, Bp.

Diófási L. (1980): A mennyiség és a minôség összefüggése Oportó, Kékfrankos és Cabernet franc szổlôfajtáknál. Borgazdaság. (1): 20-27.
Diófási L. (1985): A minổségi borszôlổtermesztés tudományos alapjai. Mezốgazdasági Kiadó Bp.

Guidoni, S. \& Schubert, A. (2000): Effects of leaf and cluster removal on anthocyanic composition of Vitis vinifera berries (cv Nebbiolo) Polifenols Communications 2000. (XX. International Conference on Polyphenols Freising-Weichenstephan) Volume I. 145-146.

Hillebrand, W., Alleweldt, G. \& Kharder, S. (1992): Weinbau Taschenbuch. Fachverlag Dr. Fraund GMBH. Mainz.

Huglin, P. \& Balthazard, J. (1976): Données relatives á I'influence du rendement sur le taux de sucre des raisins. Connais. Vigne Vin. Talence, 10:175-191.

Kállay M. \& Török Z. (1997): Determination of resveratrol isomers in Hungarian wines, Horticultural Science, 29. (3-4): 78-82.

Kiss E. \& Szốke L. (1988): Szôlōfajták termesztési értékvizsgálata. Szổloótermesztés és Borászat.

M.L. De La Hera Orts et.al. (2000): Irrigation effects on anthocyanin pigments. Polifenols Comminications 2000. (XX. International Conference on Polyphenols FreisingWeichenstephan) Volume I. 71-72.

Waterhaus et.al. (1994): A direct HPLC separation of. Wine Phenolics, Am. J. Enol. Vitic. 45. (1): 1-4. 